\title{
高炉スラグ微粉末を用いたコンクリートの各種力学特性に及ぼす 石灰石微粉末と湿潤養生の影響 \\ THE EFFECT OF LIMESTONE POWDER AND MOISTURE CURING ON PROPERTIES OF CONCRETE USING GROUND GRANULATED BLAST-FURNACE SLAG
}

\author{
佐藤幸惠*, 野口貴文**, 深尾宙彦*** \\ Sachie SATO, Takafumi NOGUCHI and Tokihiko FUKAO
}

\begin{abstract}
This paper presents of the results of the experimental study on quality improvement of the concrete using ground granulated blast furmace slag by limestone powder. We focused on the influence of limestone powder contents on restraint drying shrinkage and strength development of concrete under several curing conditions.

As the results, the compressive strength of BLP and BLP10 (LSP 10\%) are equivalent to that of BB, and that of BLP is insusceptible to demolding time compared with BB. The filling effect of LSP increased young's modulus and splitting tensile strength. The time of crack is affected by rate of decrease in mass of concrete.
\end{abstract}

\section{Keywords : Ground gramulated blast- furnace slag, Limestone powder, Restraint, Drying shrinkage, Strength development, Demolding time 高炉スラグ微粉末，石灰石微粉末，拘束，乾燥収縮，強度発現，脱型時期}

\section{1. はじめに}

近年，持続可能な社会の構築に向けて，様々な試みがなされてい る. 建築材料の分野に関しては，様々な産業副産物やリサイクル材 料を活用して省資源化を図るといったアプローチがなされており， 高炉セメントなど副産物を利用したコンクリート材料は長い歴史を 持っている．だが，高炉セメントなどの副産物を利用した混合セメ ントは，建築分野ではあまり普及が進んでいない。これは，これら の混合セメントを用いたコンクリートは, 初期強度発現が遅いこと, 湿潤養生に対する敏感性により長く湿潤養生期間を取らなければな らないこと，早期にひび割れが生じる場合があることなどから建築 物に使用する際に使いにくい問題があるためであり，利用拡大のた めにはこれらの性状を改善する手法を見出す必要がある.

そこで, 本研究では, 混合セメントの建築分野への利用拡大を最 終目的として，その性能改善手法について検討することとした。 今 回は，最も広く流通している高炉セメント B 種に対して，他の粉体 を混合して，初期強度の改善やひび割れ抵抗性の改善を試みること を検討することとした. また, 混合する粉体には容易に入手が可能 な石灰石微粉末を選定して, 各種物性值について実験を実施した.
石灰石微粉末の添加で見込まれる効果は，既往の研究報告等たと光ば1) により，初期強度の増進，緻密化などがある，収縮に関しては，加 藤ら ${ }^{2)}$ が，高炉セメントに石灰石微粉末を添加した高流動コンクリ 一トに自己収縮特性について検討し，石灰石微粉末の添加により材 齢初期の自己収縮ひずみが減少すると報告している．また，Dhirら ${ }^{3)}$ によれば，乾燥収縮は石灰石微粉末の添加に伴い減少する傾向が あると報告している，水和反応に及ぼす影響に関しては，例えば佐 川らによれば，高炉セメントに石灰石微粉末を添加した場合は，セ メント鉱物全体としての反応率はほとんど変化しないが, スラグの 反応は促進する効果があり ${ }^{4)}$, また, 初期強度の増進が認められる などの報告例えば5(6)778)もある。このことから，建築部材のように比較 的早い時期に脱型される場合に一定の効果があるか検討の余地があ ると考えられるが，養生温度を水準とした研究はなされているもの の例えば 9)，湿潤養生期間を要因として検討はほとんど行われていな い. そこで, 本研究では, 材齢初期の湿潤養生期間および石灰石微 粉末の添加率，添加方法が各種力学特性に及ぼす影響について検討 を試みた。
* 東京都市大学工学部建築学科 講師 ·博士 (工学)

** 東京大学大学院工学系研究科建築学専攻 准教授. 博士 (工学)

*** 東京大学大学院工学系研究科建築学専攻 大学院生・修士 (工学)
Assistant Prof., Dept. of Architecture, Faculty of Engineering, Tokyo City University, Ph. D. Assoc. Prof., Dept. of Architecture, Graduate School of Engineering, The University of Tokyo, Dr. Eng.

Graduate Student, Dept. of Architecture, Graduate School of Engineering, The University of Tokyo, M. Eng. 


\section{2. 実験概要}

\section{1 実験計画}

\section{(1) 実験の要因と水準}

今回実施した実験は, 各種結合材について湿潤養生条件を変化さ せた場合の強度発現性とひび割れ抵抗性を対象としたもの（シリー ズI), および石灰石微粉末を混合した場合の強度発現性とひび割れ 抵抗性の改善効果を検討したもの（シリーズ II）の 2 つのシリーズ から成る. 具体的な調合条件は, 水粉体比を $55 \%$ 一定とし, シリー ズ Iでは，普通ポルトランドセメント $(\mathrm{N})$, 高炉セメント B 種相当 として普通ポルトランドセメントに高炉スラグ微粉末を $42 \%$ 内割 混合したもの (BB), BB に石灰石微粉末を $10 \%$ 内割混合したもの (BLP) の 3 種類の調合とし，シリーズ II では，シリーズ I と同様 の $\mathrm{BB}$ と, BB 中の普通ポルトランドセメントに対して内割で石灰石 微粉末を $10 \%$ 混合したもの（BLP10）, 同样に内割で $20 \%$ 混合した もの（BLP20）の 3 水準とした. 実験の要因と水準を表 1 に示す. 作製した円柱供試体は，コンクリート打込み後，直ちに封かん状態 で静置し, 水中養生供試体は材齢 2 日で脱型後水中養生を開始した. その他の供試体は所定の材齢で脱型し, 試験材齢まで $20^{\circ} \mathrm{C} 60 \% \mathrm{RH}$ の養生室内で気中養生とした.

\section{(2)実験項目および実験方法}

実験項目は, 圧縮強度試験（JIS A 1108）, 割裂引張強度試験（JIS A 1113)，ヤング係数試験（JIS A 1149），および拘束ひび割れ試験で あり，圧縮強度試験，割裂引張試験，ヤング係数試験に用いた供試 体は， $\varphi 100 \times 200 \mathrm{~mm}$ の円柱とし，ヤング係数はコンプレッソメータ を用いて計測した. 強度試験材齢は, 各脱型材齢および材齢 28 日, 91 日で実施した。拘束ひび割れ試験は，(社）日本コンクリート工 学協会（現：日本コンクリート工学会）の「自己収縮検討委員会報 告書」 ${ }^{10)}$, 「混和材料から見た収縮ひび割れ低減と耐久性改善研究委 員会報告書」 ${ }^{11)}$ で提案されている，鉄筋を埋設した鉄筋拘束試験方 法, および丸山らの研究 ${ }^{12}$ を参考に試験条件を設定し, 各水準ごと に2 体ずつ試験体を作製して試験を実施した。その試験体概要を図 1 に示す. コンクリートの寸法は $100 \times 100 \times 1100 \mathrm{~mm}$ とし, 長さ $1200 \mathrm{~mm}$ の異形棒鋼中央部に図に示すようにひずみゲージを貼り付 け防水加工して埋設した．コンクリート打込み後から脱型までは打 込み面をポリエステルフィルムで覆い封かんするとともに, 湿布で 覆い乾燥を防いだ. その後, 所定の材齢で型枠を取り外し $20^{\circ} \mathrm{C} 60 \%$ RH の養生室内で気中養生を開始した. 打込み後から継続して埋設 鉄筋に貼りつけた鋼材のひずみを計測し，その計測值を，平面保持
表 1 実験の要因と水準

\begin{tabular}{|c|c|c|}
\hline 要因 & & 水準 \\
\hline $\begin{array}{l}\text { 結合材・粉体 } \\
\text { 種類 }\end{array}$ & I & $\begin{array}{l}\text { OPC : OPC } \\
\text { BB : OPC }(0.58)+\mathrm{BS}(0.42) \\
\text { BLP : OPC }(0.522)+\mathrm{BS}(0.378)+\mathrm{LSP}(0.10)\end{array}$ \\
\hline $\begin{array}{l}\text { （）内は各粉 } \\
\text { 体の質量比を } \\
\text { 示す. }\end{array}$ & II & $\begin{array}{l}\text { BLP20 : } \\
\text { OPC }(0.464)+\text { BS }(0.42)+\operatorname{LSP} 20(0.116) \\
\text { BLP10 : } \\
\text { OPC }(0.522)+\mathrm{BS}(0.42)+\operatorname{LSP} 10(0.058)\end{array}$ \\
\hline \multicolumn{2}{|c|}{$\begin{array}{c}\text { 水結合材比（\%） } \\
\text { (水粉体比） }\end{array}$} & 55 \\
\hline \multicolumn{2}{|l|}{ 養生方法 } & $\begin{array}{l}20^{\circ} \mathrm{C} \text { 水中養生, } 20^{\circ} \mathrm{C} \text { 封かん養生, 気中養 } \\
\text { 生 }\left(20^{\circ} \mathrm{C}, 60 \% \mathrm{RH}\right)\end{array}$ \\
\hline \multicolumn{2}{|c|}{$\begin{array}{c}\text { 脱型材齢 } \\
\text { (気中養生供試体) }\end{array}$} & $\begin{array}{l}\text { OPC }: 7 \text { 日 } \\
\text { BB : 3,7,14 日 } \\
\text { BLP : 3,7 日 } \\
\text { BLP20 : 3,7 日 } \\
\text { BLP10 : } 3 \text { 日 }\end{array}$ \\
\hline
\end{tabular}

表 2 使用材料の品質

\begin{tabular}{|c|c|}
\hline 材料 & 品質 \\
\hline $\begin{array}{c}\text { 普通ポルトランドセメ } \\
\text { ント(OPC) }\end{array}$ & $\begin{array}{c}\text { 密度 } 3.16 \mathrm{~g} / \mathrm{cm}^{3}, \mathrm{SO}_{3} \text { 量: } 2.44 \% \\
\text { 比表面積 } 3440 \mathrm{~cm}^{2} / \mathrm{g}\end{array}$ \\
\hline 高炉スラグ微粉末（BS） & $\begin{array}{c}\text { 高炉スラグ微粉末 } 4000, \mathrm{SO}_{3} \text { 量: } 2.00 \% \\
\text { 粉末度 } 3920 \mathrm{~cm}^{2} / \mathrm{g} \text {, 密度 } 2.88 \mathrm{~g} / \mathrm{cm}^{3}\end{array}$ \\
\hline 石灰石微粉末（LP） & 密度 $2.69 \mathrm{~g} / \mathrm{cm}^{3}$ \\
\hline 細骨材（S） & $\begin{array}{c}\text { 大井川水系陸砂 } \\
\text { 密度 } 2.60 \mathrm{~g} / \mathrm{cm}^{3} \text {, 吸水率 } 1.86 \% \\
\end{array}$ \\
\hline 粗骨材（G） & $\begin{array}{c}\text { 青梅産砕石 } \\
\text { 密度 } 2.64 \mathrm{~g} / \mathrm{cm}^{3} \text {, 吸水率 } 0.58 \% \\
\end{array}$ \\
\hline $\begin{array}{c}\mathrm{AE} \text { 減水剤 } \\
\text { 標準形 }(\mathrm{AD} 1)\end{array}$ & $\begin{array}{c}\text { リグニンスルホン酸化合物とポリカ } \\
\text { ルボン酸エーテルの複合体 }\end{array}$ \\
\hline $\mathrm{AE}$ 剂（AD2） & $\begin{array}{c}\text { アルキルエーテル系陰イオン界面活 } \\
\text { 性剂 }\end{array}$ \\
\hline
\end{tabular}

表 3 計画調合およびフレッシュコンクリートの性状

\begin{tabular}{|c|c|c|c|c|c|c|c|c|c|c|c|c|c|c|}
\hline \multirow[t]{2}{*}{ 調合名 } & \multirow{2}{*}{$\begin{array}{c}\mathrm{W} / \mathrm{C} \\
\left(\mathrm{W} / \mathrm{P}^{*}\right) \\
(\%) \\
\end{array}$} & \multirow{2}{*}{$\begin{array}{c}\mathrm{BS} / \\
(\mathrm{C}+\mathrm{BS})\end{array}$} & \multirow{2}{*}{$\begin{array}{l}\mathrm{s} / \mathrm{a} \\
(\%)\end{array}$} & \multicolumn{6}{|c|}{ 単位量 $\left(\mathrm{kg} / \mathrm{m}^{3}\right)$} & \multicolumn{2}{|c|}{ 化学混和剤 } & \multirow{2}{*}{$\begin{array}{l}\text { スラ } \\
\text { ンプ } \\
(\mathrm{cm}) \\
\end{array}$} & \multirow{2}{*}{$\begin{array}{c}\text { 空気量 } \\
(\%)\end{array}$} & \multirow{2}{*}{$\begin{array}{c}\text { コンク } \\
\text { リート } \\
\text { 温度 }\left({ }^{\circ} \mathrm{C}\right) \\
\end{array}$} \\
\hline & & & & W & $\mathrm{C}$ & BS & LSP & $\mathrm{S}$ & G & $\begin{array}{c}\mathrm{AD} 1 \\
\left(\mathrm{P}^{*} \times \mathrm{wt} \%\right)\end{array}$ & $\begin{array}{c}\mathrm{AD} 2 \\
\left(\mathrm{P}^{*} \times \mathrm{wt} \%\right)\end{array}$ & & & \\
\hline $\mathrm{OPC}$ & 55 & - & 47.9 & 175 & 318 & - & - & 839 & 942 & 1.0 & 0.0010 & 20.8 & 4.6 & 21.0 \\
\hline $\mathrm{BB}$ & 55 & 0.42 & 47.5 & 175 & 183 & 135 & - & 828 & 942 & 1.0 & 0.0018 & 23.0 & 4.8 & 20.5 \\
\hline BLP & 55 & 0.42 & 47.4 & 175 & 165 & 122 & 32 & 824 & 942 & 1.0 & 0.0036 & 21.0 & 4.5 & 19.5 \\
\hline BLP10 & 55 & 0.45 & 47.5 & 175 & 165 & 135 & 18 & 828 & 942 & 0.8 & 0.0040 & 20.0 & 4.0 & 20.0 \\
\hline BLP20 & 55 & 0.48 & 47.4 & 175 & 146 & 135 & 36 & 823 & 942 & 0.8 & 0.0040 & 20.5 & 3.7 & 20.0 \\
\hline
\end{tabular}




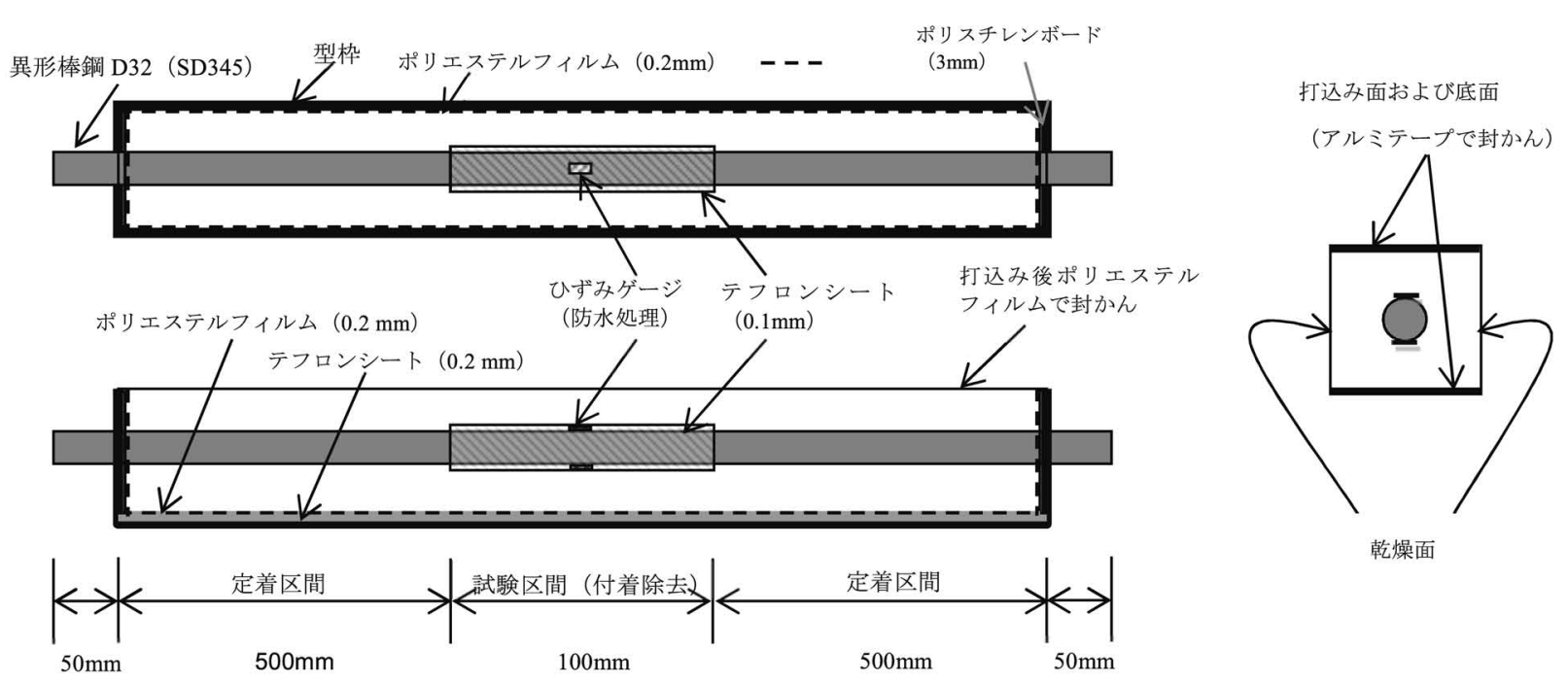

図 1 拘束ひび割れ試験供試体概要

を仮定した釣り合い式(1)に代入してコンクリート断面に生じる平 均的な収縮拘束応力を算出した ${ }^{11)}$.

$$
\sigma_{c}=-\left(E_{s} \times \varepsilon_{s} \times A_{s}\right) / A_{c}
$$

ここに,

$\sigma_{\mathrm{c}}$ : コンクリートの拘束収縮応力 $\left(\mathrm{N} / \mathrm{mm}^{2}\right)$

Es : 鋼材の弾性係数 $\left(\mathrm{N} / \mathrm{mm}^{2}\right)$

$\varepsilon_{\mathrm{s}}:$ 鋼材のひずみ

As : 鋼材の中央部断面積 $\left(\mathrm{mm}^{2}\right)$

Ac : コンクリートの純断面積 $\left(\mathrm{mm}^{2}\right)$

なお，用いた鋼材の弾性係数は，同じ ロットの試験片を用いて予め JIS Z 2241(金属材料の引張試験方法)に準じて 引張試験を行い, 応力ひずみ曲線から弾 性係数を求めた。

2.2 使用材料およびコンクリートの性質

(1)コンクリート用材料

コンクリートに使用した材料の品質を 表 2 に示す. また, 表 3 に, 計画調合と フレッシュコンクリートの試験結果を示 す. 表 3 中には結合材量に対寸る高炉ス ラグ微粉末の混合比 (BS/Binder : OPC と BS 劣 Binder とする)をあわせて示した。 普通ポルトランドセメントには，予め $5 \%$ 以下の副産物材料が混合されている が，調合上の混和材料の混合比を求める 際には便宜上計算外とした。 なお, 本研 究で使用した普通ポルトランドセメント に含まれる副産微粉は石灰石微粉末であ り，TG-DTA による化学分析（昇温速度 $10^{\circ} \mathrm{C} / \mathrm{min}, \mathrm{N}_{2}$ 雾囲気下) の結果では $3.3 \%$ 添加されていることがわかっている. 国 内で市販されている普通ポルトランドセ
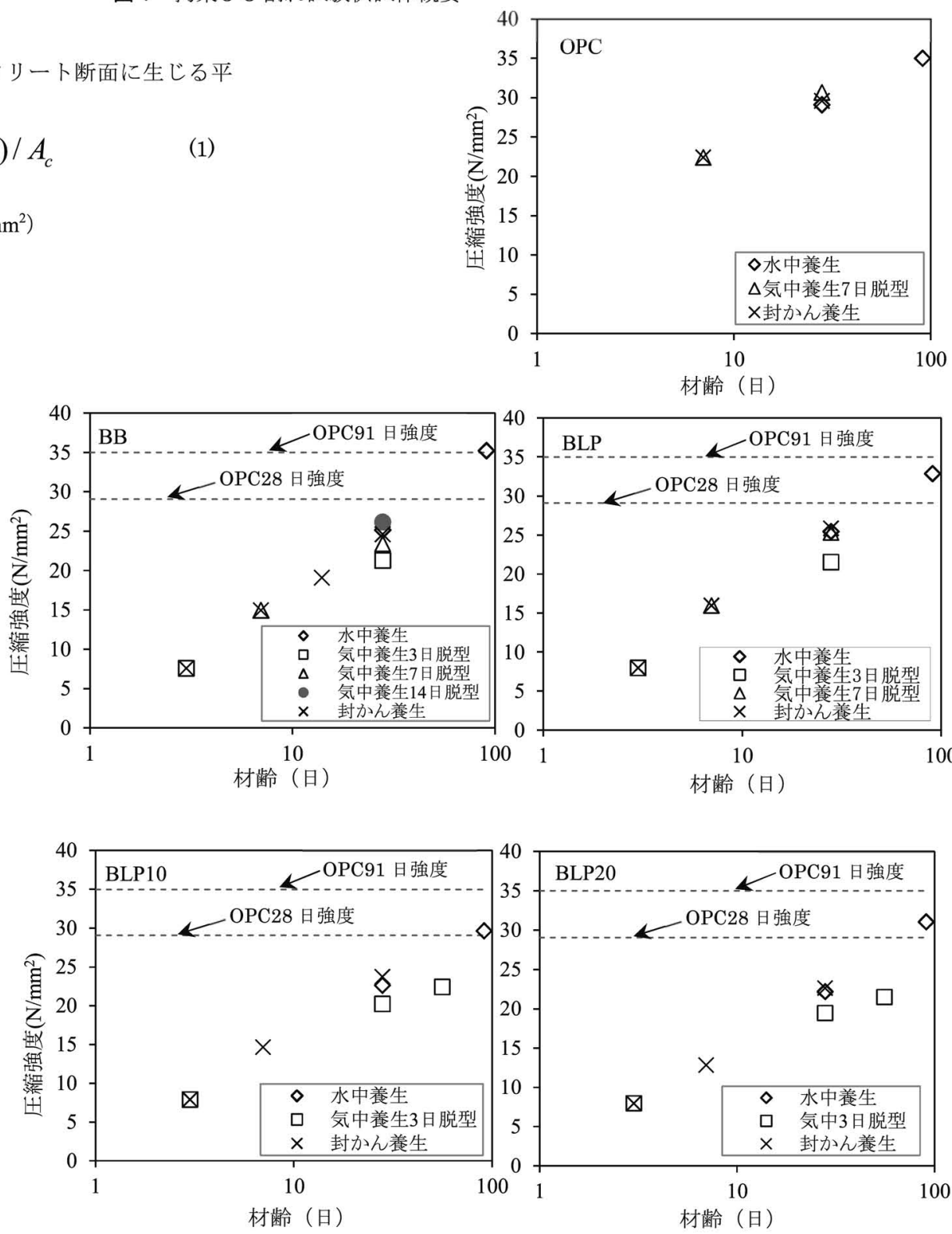

図 2 強度発現の経時変化 
メントには $5 \%$ の範囲内で石灰石微粉末以外に高炉スラグ微粉末な どが添加されているものがある. 今後それらの成分の違いによる検 証が必要であるが, 本研究では, このセメントを使用した結果につ いて示す.

\section{(2)鋼材}

使用した鋼材は，JIS G 3112(鉄筋コンクリート用棒鋼)に規定され る異形棒鋼 SD345, D32 (公称断面積 $7.942 \mathrm{~cm}^{2}$ ) を使用した. また, 同ロットの試験片を用いて実施した引張試験による弾性係数は $200 \mathrm{kN} / \mathrm{mm}^{2}$ であったので，この值を用いて収縮応力を算出した.

\section{3.実験結果と考察}

\section{1 強度発現特性}

図 2 に, 強度発現の経時変化を示す. また, 図 3 に, 封かん養生 における結合材ごとの比較を示す. 図 2 より, 強度発現性状は, OPC と比較すると, 材齢 28 日では他の調合では約 $5 \mathrm{~N} / \mathrm{mm}^{2}$ 程度低くなっ た. 材齢 91 日では, BBおよび BLP でほぼ同等の強度発現を示した ものの, BLP10, BLP20 では材齢 28 日時点と同様 $5 \mathrm{~N} / \mathrm{mm}^{2}$ 程度の強 度差が生じた。 また, 図 3 より, 石灰石微粉末を添加した場合, 材 齢 3 日では BB に比べて強度がわずかに高くなったが，材齢 7 日以 降では，BLPのみが BB を上回る結果となった.

次に, 封かん養生強度と各調合の BS/Binder 比の関係を図 4 に示 す. 図 4 中の BS/Binder 比が小さいものから BLP, BLP10, BLP20 となる. LPを添加した場合で比較すると, BS/Binder 比の小さいも のが強度発現は高い傾向がみられたが， BB と比べるとその差は小 さかった。このことから, 石灰石微粉末の添加効果が, 結合材を減 らさずに充填性を高めることによって得られるとすると，外割的な 置換についても検討する必要があると考えられる. また, 単位結合 材量では, BLP10が多いものの, 強度が BLPを下回った要因として は, 高炉スラグ微粉末量が多いためと考えられ, セメント量と混和 材量の組み合わせにより効果が異なり，これらについても今後の検 討が必要と考えられる.

一方, 湿潤養生に対する敏感性を検討するため, 材齢 3 日脱型供 試体の脱型から材齢 28 日までの質量減少率と材齢 28 日の圧縮強度 を比較した（図 5). 図より, 質量減少率の大きい BLP20 で最も圧 縮強度が小さい，封かん養生強度と気中養生 3 日脱型強度は，調合 ごとに同じ大小順となった，気中養生 7 日脱型とあわせて, 質量減 少率との関係を表したものが図 6 である. 図 6 から, 供試体の質量 減少率と圧縮強度には高い相関性がみられ, 乾燥条件に対する敏感 性は，供試体の水分逸散量を小さくすることにより低減できたと考 えられる。

圧縮強度に関しては，BLPの場合において脱型材齢の影響を小さ く出来, 強度発現にも寄与が認められたが，その効果の範囲は限定 的であると考えられる.

次に, 図 7 に圧縮強度と割裂引張強度との関倸を示す. 圧縮強度 に対する割裂強度の比はおおむね $1 / 12$ 程度となった。野口らによる 高強度コンクリートの場合の圧縮強度と引張強度との関係式 ${ }^{13)}$ を図 中の点線に示す．また，BB における回帰式を図中に実線で示す. 2 つの関係式の相関係数 R はいずれも 0.93 であったが, 野口ら ${ }^{13)}$ による式では，低強度域で実測值から外れる傾向がみられ，今回の 結果から算出した式は, 低強度域では相関性が高いものの, 高強度

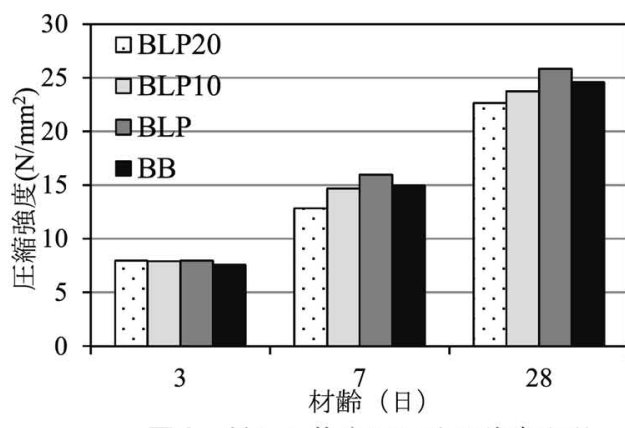

図 3 封かん養生における強度発現

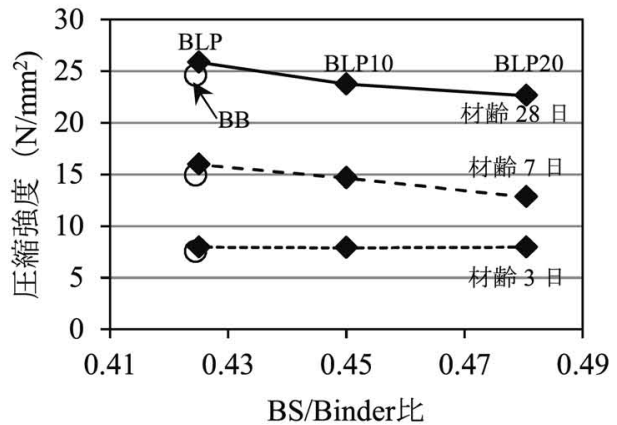

図 4 BS/Binder 比と圧縮強度の関係

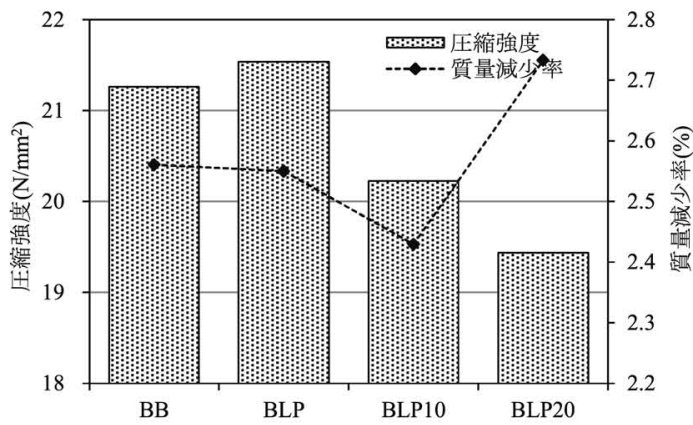

図 5 調合別質量減少率と気中養生強度（3日脱型）

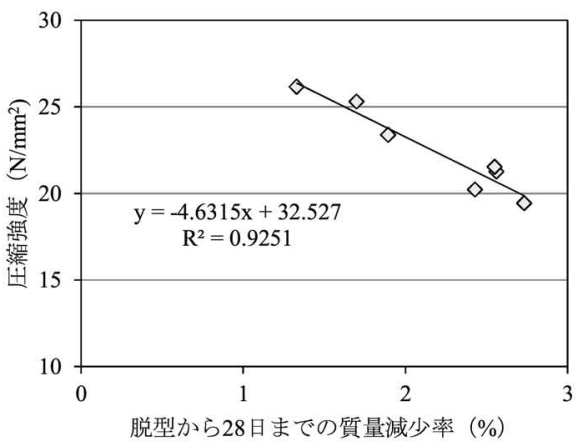

図 6 質量減少率と気中養生強度

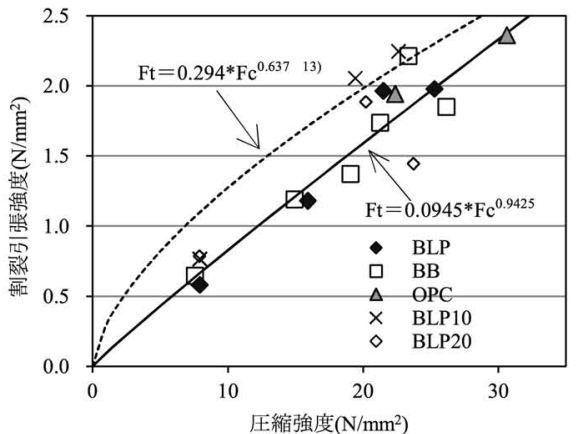

図 7 質量減少率と気中養生強度 
域で相関性が低下したことが要因と考えられる．割裂引張強度は， 材齢初期の低強度域では結合材種類による差はみられなかった，材 齢 28 日以降では BLP, BLP10, BLP20 が BB と同程度の圧縮強度に と比較して割裂引張強度が高くなる傾向がみられた．ただし，石灰 石微粉末の添加量や添加率との明確な関係は見いだせなかった。

\section{2 ヤング係数}

圧縮強度とヤング係数の関係を図 8 に示す．また，次式に示す NewRC 式 ${ }^{13)}$ を用いてヤング係数を算出し, 図中に示した. また, OPC に関しては(2)式の $\pm 20 \%$ を示す線も同時に図示した.

$$
E=k_{1} \times k_{2} \times 3.35 \times 10^{4} \times\left(\frac{\gamma}{2.4}\right)^{2} \times\left(\frac{\sigma_{\mathrm{B}}}{60}\right)^{\frac{1}{3}}
$$

ここに,

E : コンクリートのヤング係数 $\left(\mathrm{N} / \mathrm{mm}^{2}\right)$

$\gamma:$ :コクリートの単位容積質量 $\left(\mathrm{t} / \mathrm{m}^{3}\right)$

$\sigma_{\mathrm{B}}$ :コンクリートの圧縮強度 $\left(\mathrm{N} / \mathrm{mm}^{2}\right)$

$\mathrm{k} 1:$ 粗骨材の種類により定まる修正係数

$\mathrm{k} 2$ : 混和材の種類により定まる修正係数

なお, $\gamma=2.3$, OPC については $\mathrm{k} 1=\mathrm{k} 2=1.0, \mathrm{BB}, \mathrm{BLP}, \mathrm{BLP} 10$, BLP20 については $\mathrm{k} 1=1.0, \mathrm{k} 2=0.95$ を用いた.

図 8 より，ヤング係数は概ね式(2)を上回り，圧縮強度が高くなる ほど, 図 8 中に示した(2)式の+20\%より大きくなる傾向がみられた. 石灰石微粉末を使用した場合は, BB と比較すると同一強度におい てヤング係数が高くなる傾向がみられた.これは既往の研究報告 ${ }^{5)}$ と同様の傾向となり, 圧縮強度の高い範囲で顕著となった。 圧縮強
度が高いのは水中養生および封かん養生で，水和反応が十分に進行 したためと考えられる．ただし，平田ら ${ }^{81}$ は，石灰石微粉末の置換 率の増加に伴い, ヤング係数が低下する減少を報告しており, さら に広範囲な置換率での検討と長期的な強度発現性状をあわせて評価 する必要があると考えられる.

\section{3 拘束収縮応力}

図 9 に, 拘束ひび割れ試験による拘束収縮ひずみの経時変化を 示す．なお，今回は試験体 2 体で行ったたが，試験体間の差がほと んど無かったため, 水準ごとの平均值を用いて考察した. 図より, 脱型材齢が長い方が拘束収縮ひずみは大きくなり，また，ひび割れ 発生に伴う収縮緩和までの期間が長い傾向がみられた，BLP では， 拘束収縮ひずみの最大值は，3 日脱型と 7 日脱型で小さくなった. 高炉スラグ微粉末を混合した調合では，目視でのひび割れ確認が難

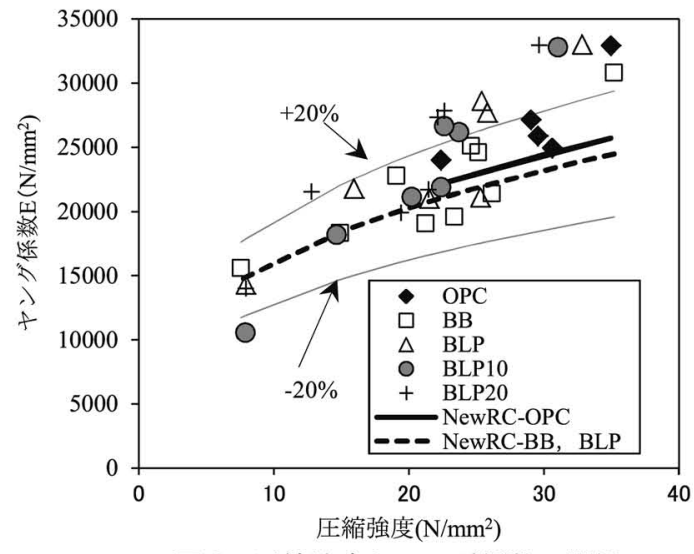

図 8 圧縮強度とヤング係数の関係
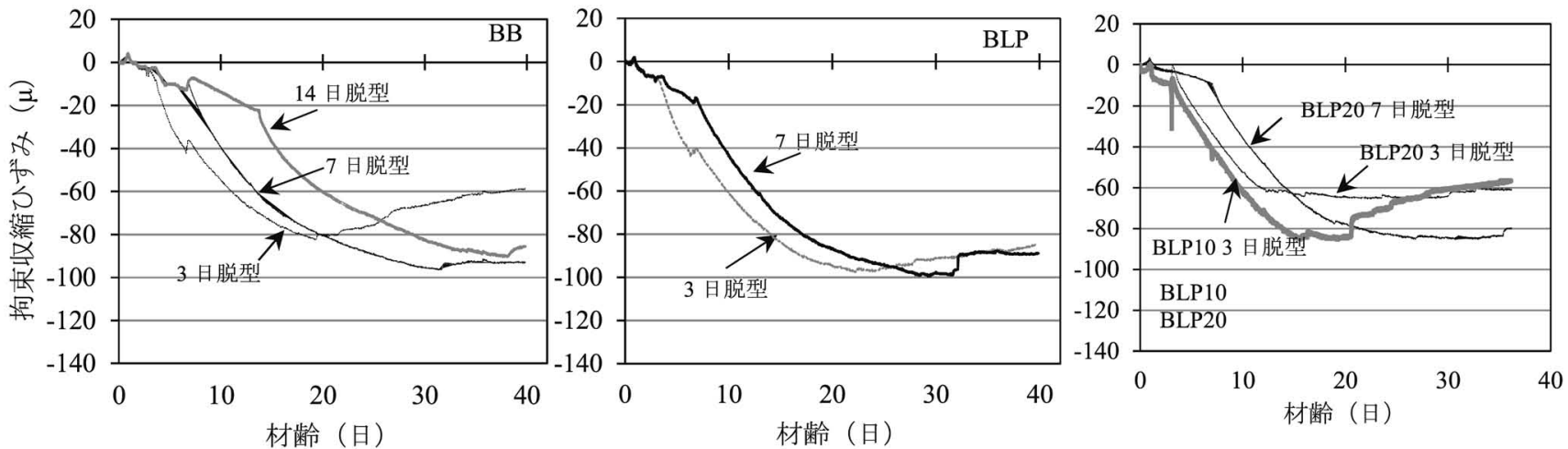

図 9 拘束収縮ひずみの経時変化
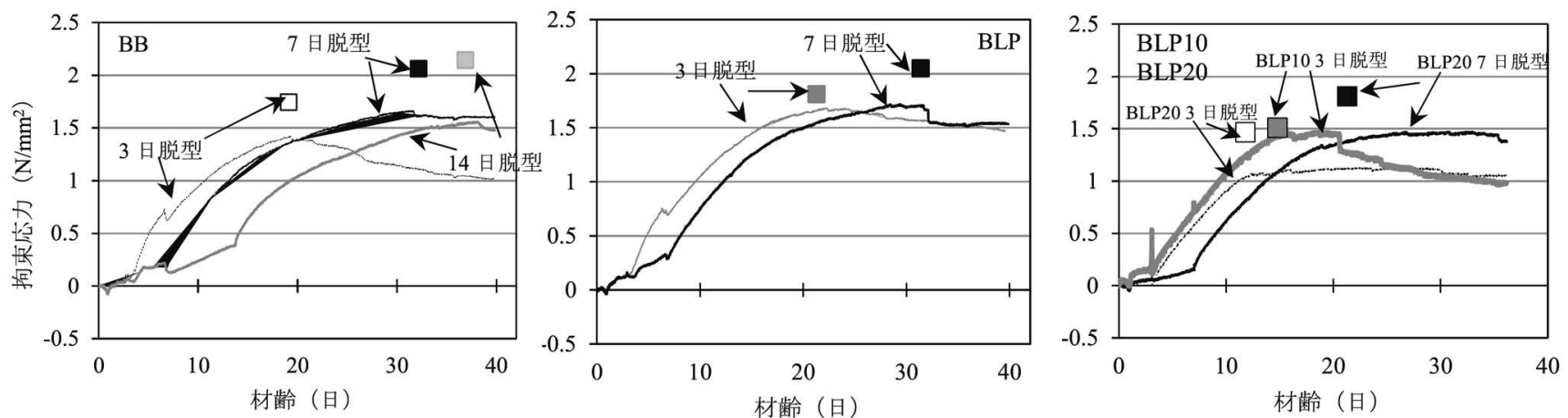

図 10 拘束応力の経時変化 
しく,経時的な収縮ひずみの経時変化と比較しながら判定を行った. 結果として生じたひび割れは, 表面に微細なひび割れが多数発生す る結果となった，そのため, ひび割れ発生による応力緩和が緩慢と なり,ひび割れの進展が緩やかに進行する様子が確認された. 次に, (1)式を用いて拘束収縮応力を算出したものを図 10 に示す. 図中の口 は, 材齢と割裂引張強度の関係から求めたひび割れ発生時の引張強 度の計算值である. BB では, 脱型材齢が遅くなるにつれ, ひび割 れ発生材齢および拘束収縮応力は増加するが, 7 日と 14 日ではその 差は小さくなっており, BB を使用する場合は, 7 日以上の湿潤養生 期間があればひび割れ抵抗性を向上させるものと考えられる. BLP においても脱型材齢が長くなると同様の傾向がみられたが， 3 日脱 型と 7 日脱型の差が小さく, BB と BLPの 3 日材齢を比較すると, BLPの方が拘束応力が大きく, かつ, ひび割れ発生材齢も長くなっ たことから，材龃初期の脱型に対する改善効果が認められた. 図 11 に, 各結合材の 3 日脱型の場合を比較した結果を示す. BB に対し て, BLP20 は拘束応力およびひび割れ発生材齢ともに小さくなって いる. また, BLP10 はBLP とひび割れ発生までの拘束応力変化は同 等であるが, ひび割れ発生材齢が早く, ひび割れ発生時の拘束応力 は BB と同等となった.

石灰石微粉末を用いた場合の乾燥収縮に関しては, Dhir ら ${ }^{3)}$, 大 原ら ${ }^{14)}$ は添加量が多いほど乾燥収縮は小さいとしているが, セメン 卜種類によっては石灰石微粉末の添加により乾燥収縮率が大きくな る場合, セメント量の増加により乾燥収縮率が大きくなる場合があ ること ${ }^{15)}$ が報告されているが, 今回の実験水準の範囲では, BLPに ついてのみがひび割れ抵抗性に対して改善効果が認められた.さら に, 石灰石微粉末の添加量の影響と湿潤養生期間の影響を比較する と, 今回の実験水準の範囲では, 調合要因よりも湿潤養生期間を長 くする方が明確にひび割れ抵抗性を改善できたと考えられるため, 今後これらの相互関係に基づく検討が必要と考えられる.

表 4 に発生材齢, ひび割れ発生時の拘束応力および引張強度, 応 力/強度比を示す. また, 図 12 にひび割れ発生材齢と応力強度比の 関係を示す. 応力/強度比は BLP20 を除いて 0.7 から 0.9 に分布し, 既往の調查 ${ }^{16)}$ と同等の結果となった. また, 既往の研究では, 脱型 材齢と材齢とひび割れ発生材齢との関係が明確となっていない報告 もあるが ${ }^{11)}$, 今回の結果では, 脱型材齢が長くなるとひび割れ発生 材齢も長くなる傾向がみられた. また, 結合材に対して石灰石微粉 末の量が多いBLP20ではひび割れ発生材齢が早まり, 応力強度比も 小さくなる傾向を示した.

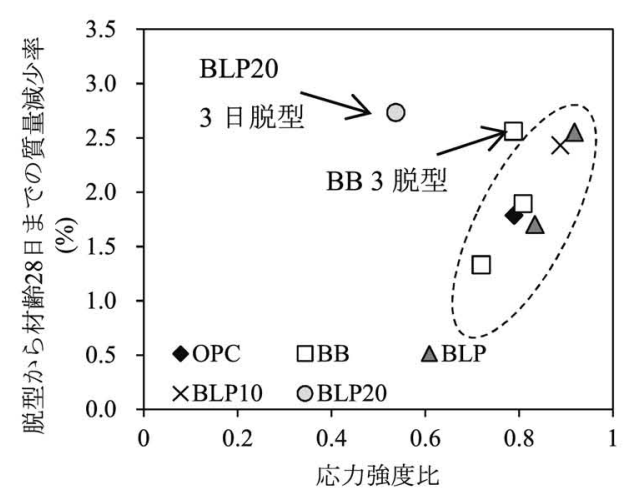

図 13 応力強度比と質量減少率の関係

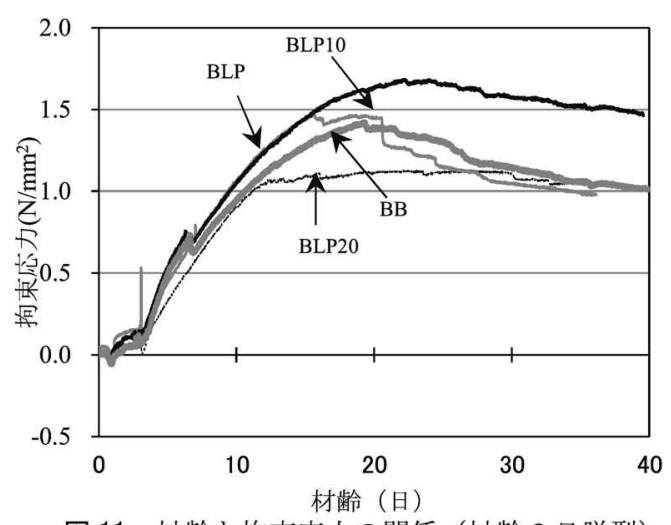

図 11 材齢と拘束応力の関係（材齢 3 日脱型）

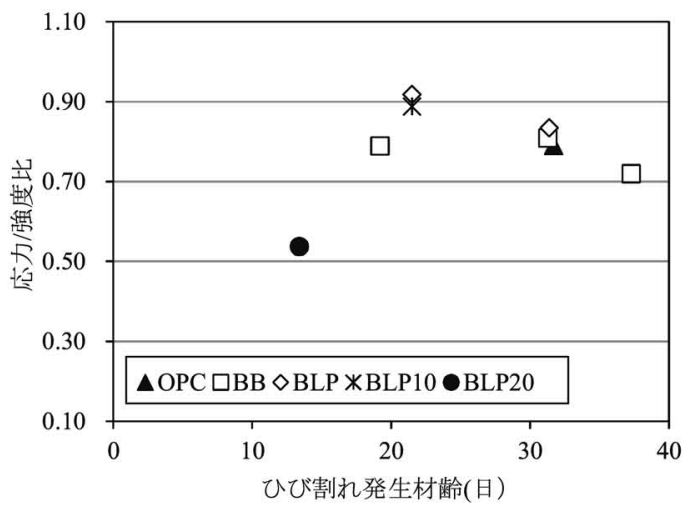

図 12 ひび割れ発生材齢と応力強度比の関係

表 4 ひび割れ発生材齢, 引張強度, ひび割れ発生応力

\begin{tabular}{l|c|c|c|c}
\hline $\begin{array}{l}\text { 結合材およ } \\
\text { び脱型材齢 }\end{array}$ & $\begin{array}{c}\text { ひび割 } \\
\text { れ発生 } \\
\text { 材齢 } \\
\text { (日) }\end{array}$ & $\begin{array}{c}\text { ひび割 } \\
\text { れ発生 } \\
\text { 応力 } \\
\left(\mathrm{N} / \mathrm{mm}^{2}\right)\end{array}$ & $\begin{array}{c}\text { ひび割れ } \\
\text { 発生時の } \\
\text { 引張強度 } \\
\left(\mathrm{N} / \mathrm{mm}^{2}\right)\end{array}$ & $\begin{array}{c}\text { 応力/強度 } \\
\text { 比 }\end{array}$ \\
\hline OPC 7 日 & 31.7 & 2.14 & 2.71 & 0.79 \\
\hline BB 3 日 & 19.2 & 1.38 & 1.75 & 0.79 \\
\hline BB 7 日 & 31.3 & 1.65 & 2.04 & 0.81 \\
\hline BB 14 日 & 37.3 & 1.54 & 2.14 & 0.72 \\
\hline BLP 3 日 & 21.5 & 1.68 & 1.83 & 0.92 \\
\hline BLP 7 日 & 31.4 & 1.71 & 2.05 & 0.83 \\
\hline BLP10 3 日 & 21.5 & 1.67 & 1.88 & 0.89 \\
\hline BLP20 3 日 & 13.4 & 1.08 & 2.01 & 0.54 \\
\hline
\end{tabular}

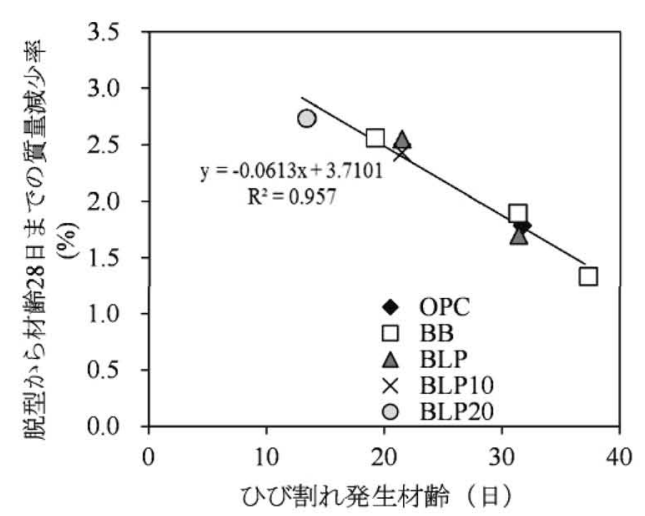

図 14 質量減少率とひび割れ発生材齢の 
乾燥状態と応力強度比の関係を図 13 に示す. 図より, 曲線で囲 まれた範囲では, 結合材種類に関わらず質量減少率の増加に伴い応 力強度比も大きくなる傾向が見られたが，BB および BLP20の 3 日 脱型のような, 組織の緻密化が十分でないうちに脱型した供試体で は応力強度比が小さくなる傾向がみられた.これは, 乾燥しや寸く, 組織の緻密化や強度発現が十分でない場合は表層部に多くのひび割 れが生じやすく，ひび割れ抵抗性が低下するためと考えられる。 ま た, 図 14 にひび割れ発生材齢と質量減少率の関係を示す. 図より, 今回実施した実験水準では, 両者の関係は結合材種類に関わらず直 線性を持つ傾向がみられた. また, 質量減少率が高いほど早期にひ び割れを生じる結果となった。

\section{4. まとめ}

本研究では, 高炉セメントを用いたコンクリートの強度発現性, ひび割れ抵抗性に対する石灰石微粉末の効果ならびに湿潤養生の影 響について検討を行った，得られた結果を以下に記す。

（1）石灰石微粉末を添加した場合，10\%の場合は高炉セメント B 種相当と比較して強度発現の差は小さく, $20 \%$ 添加するとやや強度 の低下がみられた. また, BS/Binder 比は小さいほうが強度発現は大 きい.

（2）圧縮強度に対する脱型時期の影響で比較すると，BLP は BB よ りも脱型時期の影響を受けにくくなる傾向がみられ, 石灰石微粉末 による充填効果があったと推察された.

（3）ヤング係数, 割裂引張強度は, 同程度の圧縮強度の場合, 石灰 石微粉末添加によって大きくなる傾向が見られた.

（4）石灰石微粉末の添加は，10\%までの置換率では，最大収縮ひず みあるいは拘束応力の大きさにはあまり影響しないが，湿潤養生期 間を長くすることによりひび割れ発生材齢を遅くする効果が認めら れた.

（5）今回の実験水準において, 質量減少率とひび割れ発生材齢との 関係は，結合材種類に関わらず．乾燥による質量減少率が大きいほ ど早期にひび割れが発生し, 脱型材齢が早いと応力強度比が低下寸 る.

\section{謝辞}

本研究の実施に際し，鐵鋼スラグ協会より材料提供に関して協力 を得たここに記して謝意を表す。また，実験の遂行にあたり，林 千晴さん（株式会社山下設計, 当時東京都市大学卒論生), 並木桃子 さん（大和八ウス工業株式会社, 当時東京都市大学卒論生), 西尾悠 平君（東京大学大学院生）の協力を得た.ここに記して謝意を表し ます。

\section{参考文献}

1)国府勝郎，兼安真司，黑済世雄：鉱物微粉末を用いたコンクリートの乾燥 収縮とひび割れ性状, セメント・コンクリート論文集, No.49, pp.620-625, 1995.12

2)加藤 弘義, 宫川 豊章, 中村 明則, 土井 宏行: 高炉スラグ微粉末を使 用した高流動コンクリートの自己収縮に与えるセッコウ及び石灰石微粉末 の影響,土木学会論文集,711, V-56, pp.111-124, 2002.8

3) R. K. Dhir, M. C. Limbachiya, M. J. McCarthy, A. Chaipanich : Evaluation of

Portland Limestone Cements for Use in Concrete Construction, Materials and
Structures, volume40,Issue5, pp. 459-473，2007.6

4)佐川孝広,名和豊春: 高炉セメントの水和反応に及ぼす石灰石微粉末の影響, 日本コンクリート工学協会年次論文集，Vol.29, No.1，pp.93-98，2007.8 5)王鉄成，長岡誠一，中野錦一：セメントの一部を石灰石微粉末で置換した コンクリートの強度特性, セメント・コンクリート論文集 No.49, pp.564-569,1995.12

6)原田裕治，志澤三明，小谷博 : 高炬セメントの諸物性におよぼすスラグ微 粉末および石灰石微粉末の影響，セメント技術年報 40，pp.64-70，1986.12 7)セメント協会 : 石灰石微粉末専門委員会報告書, 2001.10

8)平田隆祥, 竹田宣典, 十河茂幸 : 石灰石微粉末の多量添加がコンクリート の強度特性に及ぼす影響, セメント・コンクリート論文集 No.49, pp.204-209,1995.2

9)E.F. Irassar et al. : Influence of limestone content, gypsum content and fineness on early age properties of Portland limestone cement produced by inter-grinding, Cement \& Concrete Composites, 33-2, pp.192-200,2011.2

10)（社）日本コンクリート工学協会 : コンクリートの自己収縮研究委員会報 告書 2002

11）(社）日本コンクリート工学協会 : 混和材料からみたひび割れ低減と耐久 性改善委員会報告書 2010

12)丸山一平，亀田昭一，鈴木雅博，佐藤良一：RCプリズムにおける自己収縮 による微細ひび割れ発生と収縮応力挙動,コンクリート工学年次論文集, Vol.28, No.1, pp.587-592, 2006.7

13)野口貴文, 友澤史紀 : 高強度コンクリートの圧縮強度と各種力学特性との 関係, 日本建築学会構造系論文集, 第 472 号, pp.11-16,1995.6

14)大原功:高炉セメントの諸特性におよぼす石灰石粉末の影響、セメント技術 年報 32, pp.104-107, 1978.12

15)Peter Hawkins, Paul Tennis and Rachel Detwiler: The Use of Limestone in Portland Cement: A State-of-the-Art Review, Portland Cement Association, 2003 16)濱永康仁：コンクリート部材に生じる収縮ひび割れ発生条件に関する研究, 大分大学学位請求論文, 2007.3

(2012年 5 月 10 日原稿受理，2012年10月15日採用決定） 